The University of London has also recently 'recognised' the new institution as a 'school' of the University, and four chairs have now been advertised, in medicine, surgery, obstetrics and gynæcology, and pathology. Presumably, assistants will also be needed for each unit, and it may be anticipated that courses will also be delivered from time to time by eminent physicians, surgeons and others not permanently attached to the School.
In addition, the courses in present postgraduate centres will still be made use of so far as possible.

Thus, after many vicissitudes, a postgraduate medical school worthy of the great Metropolis has come into being, which it may be anticipated will in the future raise the standard of professional skill among the great body of medical practitioners, and will advance the progress of medical science by research carried out within its walls.

\title{
Obituary
}

\section{Prof. Camille Matignon}

$\mathrm{A}^{\mathrm{B}}$ RTHEME CAMILLE MATIGNON, president of the French Chemical Society, who died suddenly in Paris on March 18, was a leading figure in pure chemistry and a great exponent of chemical technology. Matignon was born at Saint Mauriceaux-Riches-Hommes, Yonne, on January 3, 1867, and entered the Ecole Normale, Paris, in 1886 ; three years later he became assistant to Berthelot at the Collège de France and commenced a long series of original contributions to our knowledge of thermochemistry. After spending five years at the University of Lille as lecturer and professor, he was appointed as a temporary professor at the Collège de France in 1902 , a supplementary professor in 1903 and, on the death of Berthelot, became professor of inorganic chemistry in 1908, holding this post until his death.

Matignon early concerned himself with the great problem of the fixation of atmospheric nitrogen and the synthetic production of ammonia; he studied the direct combination of many of the metals with nitrogen, showing that zinc dust always contains zinc nitride, and preparing the nitrides of a number of the rare earth metals. Certain of the nitrides, such as those of silicon and aluminium, were probably formed during the cooling of the earth and, by the action of water vapour, gave ammonia, the first form in which nitrogen became available for assimilation by plant life. Matignon maintained that the increased use of artificial nitrogenous fertilisers was essential to the development of French agriculture; he followed up the advocacy of this principle by working out methods for the economic production of phosphates and potassium salts for use as manures.

With the aid of the calorimetric bomb, Matignon determined the heats of combustion of a long series of substances and, since many of these were closely related organic compounds, he was able to deduce a number of interesting generalities from the heats of formation. His more extended studies of the part played by heat in chemical reactions led him to the statement of an empirical law of thermodynamics which Nernst termed the 'Le Chatelier-Matignon rule'. This states that for gaseous equilibria in which one gaseous and one or more solid phases are concerned (sublimation of solids, dissociation of calcium carbonate, etc.), the relation $Q / T=32$ holds approximately in all cases, $Q$ being the heat evolved at constant pressure and $T$ the absolute temperature at which the gaseous pressure attains one atmosphere. This empirical law is an extension to chemical dissociation of Trouton's law concerning heats of vaporisation. The Le Chatelier-Matignon rule can be stated in several ways and may be used to foretell whether certain reactions can take place and whether they are reversible. Thus, it was foreseen that hydrogen sulphide should react with potassium carbonate, but not with sodium carbonate at the ordinary temperature; these deductions were verified by experiment. Matignon's achievements in these and many other fields were recognised by his election to the Institut de France in 1926 .

Matignon was an eloquent speaker and wrote in a lucid, convincing style. He assumed the editorship of the Journal of the French Society of Industrial Chemistry at its inception in 1918, and the editorial which he wrote each month until the end of his life was read with interest by the whole chemical world ; the last of these articles-on the fiftieth anniversary of the death of Dumas-appears in the March number of Chimie et Industrie which was published a few days ago. Matignon's striking personality and his gay, vivacious enthusiasm made him a notable figure. He did much to promote the re-establishment of those normal relations between scientific men throughout the world which had been so rudely shattered by the War; he had many friends far outside his own country who will remember him with respect and affection.

W. J. Pope.

\section{Mr. E. G. B. Meade-Waldo}

IT is with great regret that we have to record the death of $\mathrm{Mr}$. Edmund Gustavus Bloomfield Meade-Waldo, of Stonewall Park, Chiddingstone, Kent, who died on February 24, aged seventynine years. Only son of Mr. Edmund Waldo Meade-Waldo, of Hever Castle and Stonewall Park, he was born at Holly Brook, Co. Cork, on February 8, 1855, and educated at Eton and Magdalene College, Cambridge. His room at Eton was a menagerie of wild animals, and rumour has it that, while at Eton, his overpowering ambition was to kill one of the red-deer in Windsor forest, and that this ambition was fulfilled. In 1880 he married Ada Coralie, a daughter of the 
late Lord Justice Baggallay, and he and his wife went to live for some time at Rope Hill in the New Forest. The New Forest, as was only natural, brought out all that passionate love of Nature and animal life which had already begun to show itself at Eton.

Like his life-long friend, Herbert St. Quintin, of Scampston Hall, Yorkshire, who died a year ago, Meade-Waldo was a born naturalist, and both were fortunate in having leisure to develop more and more their powers of observation in all branches of natural history. It is said that they corresponded almost every day of their lives and, needless to say, the subject of this correspondence formed an almost daily diary of what they had observed in the field of Nature. If the many facts comprised in these remarkable series of letters could be gathered up, it is probably no exaggeration to say that they would vie with those contained in White's "Natural History of Selbourne".

Both these friends were ardent hawkers and, in this fascinating pursuit, such other well-known hawkers and naturalists as Lord Lilford, Aubyn Trevor-Battye, W. R. Ogilvie-Grant, the Hon. Gerald Lascelles, Col. H. Barclay and the Rev. Gage Freeman and others, were very closely associated. Meade-Waldo's diaries contain many records of famous hawks and their prowess in the chase.

Meade-Waldo's life represents a page in the history of ornithology which is not likely to be rewritten. Another of his intimate friends was the late Henry Elwes, a man passionately fond of God's open spaces in many countries, a naturalist in every sense of the word, the author of one of the finest books on trees ever written. Lord Grey of Fallodon was another friend after his own heart, and Herbert St. Quintin, MeadeWaldo and Grey forgathered every year at Fallodon. All three have died in the last year and to those in sympathy with the point of view they represented, their passing will inevitably represent a lost link with the ornithology of the past.

But Meade-Waldo's activities in the realms of Nature were not confined to his own broad acres or those of his friends. He studied birds in Spain, as also in Morocco, where during a long residence he explored the Atlas Mountains in days when travel in that country was not the easy matter it is now. He was also intimately acquainted with the birds of the Canary Islands, and was one of the late Lord Crawford's guests on his voyage to Madagascar and the Comoro Group, in his famous yacht, the Valhalla.

Meade-Waldo was also an ardent supporter of the various societies for the protection of bird life, the fauna of the Empire, and the establishment of nature reserves, while he took the deepest interest in the welfare of the Zoological Society of London, of which he was a vice-president and a member of the Council. He was indefatigable in his attendance at the many meetings which such work involved.

\section{Mr. John Power}

Bx the death on January 27, at Rosebank, near Cape Town, of Mr. John Power, one of the few remaining direct links with the Royal Observatory, Greenwich, under the administration of Sir George Airy, has been broken.

John Power was born in Waterford, Irèland, on July 14, 1860. He entered the Greenwich Observatory in 1875, six years before the retirement of Airy. In 1891 he left to take up the appointment of secretary and librarian to the Cape Observatory, under Sir David Gill. In 1895 he was appointed a junior assistant, being succeeded as secretary, after a short interval, by the late Dr. R. T. A. Innes, who afterwards became the first Union Astronomer. In 1905 Power was promoted to the rank of assistant. From 1897 until his retirement in 1920 he was in charge of the miscellaneous computing department. In that capacity he was responsible for the preparation and proof reading of the following catalogues (the dates of publication are in brackets) :-Cape General Catalogue for 1890 (1898); the Cape General Catalogue for 1865 (1899); the Cape Astrographic Standard Star Catalogue (1906); the Cape Catalogues of Special Stars for 1900 (1906) ; the Cape Catalogue (Boss's Stars South of $-36^{\circ}$ ) (1907); the First Cape Fundamental Catalogue for 1900 (1915); the Second Cape Fundamental Catalogue for 1900 (1920); and the Cape Zone Catalogue of 20,843 stars for 1900 (1923). He showed remarkable industry and devotion in this work, spared no efforts to ensure accuracy in all details and was very skilled in marshalling large masses of numerical data. $\mathrm{He}$ rendered also very valuable services in connexion with the revision and control of the co-ordinates of the plates for the Cape zones of the Carte-duCiel work and in their preparation for press. For many years he was a regular and active observer with the transit circle.

Power was much interested in local and municipal affairs. He was largely responsible for the inception of a public library in Observatory (the suburb adjacent to and named after the Cape Observatory) of which he was chairman for many years preceding his death. He was also for many years a member of the Cape School Board, of which he became successively vice-chairman and chairman. After his retirement, he devoted a great deal of his time to the work of this body, on which he will be greatly missed. Financial approval for carrying out the programme of the Board was often difficult to obtain, but Power's Irish extraction showed itself in his love of a fight and he was at his best in defending his policy and attacking his opponents. The cause of elementary education at the Cape owes a great deal to his efforts.

Mr. Power was a widower and his only son, who had had a brilliant career at Oxford as a Rhodes scholar, was killed in action in East Africa. 